\title{
Overfishing, disease, habitat loss, and potential extirpation of oysters in upper Chesapeake Bay
}

\author{
Michael J. Wilberg ${ }^{1, *}$, Maude E. Livings ${ }^{1,2}{ }^{,}$Jennifer S. Barkman ${ }^{1}$, Brian T. Morris ${ }^{3}$, \\ Jason M. Robinson ${ }^{1}$ \\ ${ }^{1}$ Chesapeake Biological Laboratory, University of Maryland Center for Environmental Science, PO Box 38, Solomons, \\ Maryland 20688, USA \\ ${ }^{2}$ Present address: Maryland Department of Natural Resources, Tawes State Office Building 580 Taylor Avenue, B2, \\ Annapolis, Maryland 21401, USA \\ ${ }^{3}$ Present address: Northrop Grumman Corporation, 43865 Airport View Drive, Hollywood, Maryland 20636, USA
}

\begin{abstract}
The fishery for eastern oyster Crassostrea virginica in Chesapeake Bay, USA, was the biggest oyster fishery in the world and the largest fishery in the US in the late 1800s. The population has declined substantially because of overfishing, disease, and habitat loss. We developed a statistical model to simultaneously estimate effects of fishing and disease on oysters in upper Chesapeake Bay during 1980 to 2009. We compared the model estimates of abundance in 2009 to that prior to large-scale commercial fishing. We found that oyster abundance declined $99.7 \%$ (90\% credibility interval [CI], 98.3 to $99.9 \%$ ) since the early 1800 s and $92 \%$ (90\% CI, 84.6 to $94.7 \%$ ) since 1980 . Habitat area declined nearly $70 \%(90 \%$ CI, 36.2 to $83.3 \%$ ) during 1980 to 2009 . Natural mortality (mortality from all non-fishing sources) of market-sized oysters varied substantially and increased during 1986 to 1987 and 2000 to 2002, and natural mortality of small oysters approximately doubled after 1986. The exploitation rate varied over time and averaged $25.1 \% \mathrm{yr}^{-1}$ (90 \% CI, 16.1 to $33.1 \%$ ) during 1980 to 2008. Fishing and disease have had substantial negative impacts on the population, but effects of fishing have been stronger than increased natural mortality. We recommend a moratorium on fishing to minimize the risk of extirpation and provide an opportunity for recovery.
\end{abstract}

KEY WORDS: Crassostrea virginica $\cdot$ Multiple stressors $\cdot$ Population dynamics $\cdot$ Bayesian analysis

\section{INTRODUCTION}

In 1701, a traveler to Chesapeake Bay, USA, wrote, 'The abundance of oysters is incredible. There are whole banks of them so that the ships must avoid them.' (Hinke 1916, p. 35). Since then, the population has declined substantially and oyster reefs are no longer a hazard for navigation (Kennedy \& Breisch 1983, Rothschild et al. 1994). The decline in eastern oyster Crassostrea virginica is a cause for concern because of the commercial value of its harvests and the ecosystem services it provides have declined (Jackson et al. 2001, Kemp et al. 2005, Lotze et al. 2006, Coen et al. 2007, Grabowski \& Peterson 2007). Oysters are ecosystem engineers, constructing habitat for themselves as well as for a multitude of other organisms (Coen et al. 1999, 2007, Peterson et al. 2003, Grabowski et al. 2005, Fulford et al. 2010). They also provide important ecosystem services like nutrient cycling (Dame \& Libes 1993, Fulford et al. 2007) and benthic-pelagic coupling (Baird \& Ulanowicz 1989, Porter et al. 2004). Additionally, increasing oyster populations may have a substantial influence on reducing effects of anthropogenic eutrophication (Cerco \& Noel 2007, Fulford et al. 2010). Oyster populations have declined substantially throughout the world because of multiple stressors including fishing, disease, and habitat loss and degradation, but the amount of decline has 
usually been determined by rough proxies, often harvest (Jackson et al. 2001, Kirby 2004, Lotze et al. 2006).

The importance of multiple stressors on population dynamics is increasingly noted, but their effects are often difficult to evaluate because of limited data or understanding of processes (Patterson 1996, Harvell et al. 2002). For example, methods of looking at stressors individually often require that effects of other stressors are known a priori or assumed constant over time (but see Lenihan \& Peterson 1998), and models that include multiple simultaneous effects are often too complex to estimate all of the parameters given the available data (Patterson 1996). Studies that have been conducted usually provide general conclusions about the dynamics of the system (e.g. Hofmann et al. 1995, Powell et al. 1996) instead of making specific estimates and predictions, which are necessary for science-based management of natural resources (Patterson 1996). In the present study, we focus on an analysis of multiple stressors in the eastern oyster population in upper Chesapeake Bay as a case study of the effects of fishing and disease and their implications for restoration efforts.

Overfishing has been identified as the primary culprit in the initial decline of Chesapeake Bay oysters (Rothschild et al. 1994, Jackson et al. 2001), but 2 diseases, MSX and Dermo, caused by Haplosporidium nelsoni and Perkinsus marinus, respectively, have also played an important role since the 1950s (Andrews 1988, Burreson \& Ragone Calvo 1996, Ford \& Tripp 1996). Large-scale commercial fishing of oysters in Maryland, USA, began in the mid-1800s (Kennedy \& Breisch 1983). By the late 1800s, Maryland had the largest oyster fishery in the world, which at its peak harvested 15 million bushels (1 bushel: 46 li Fig. 1)

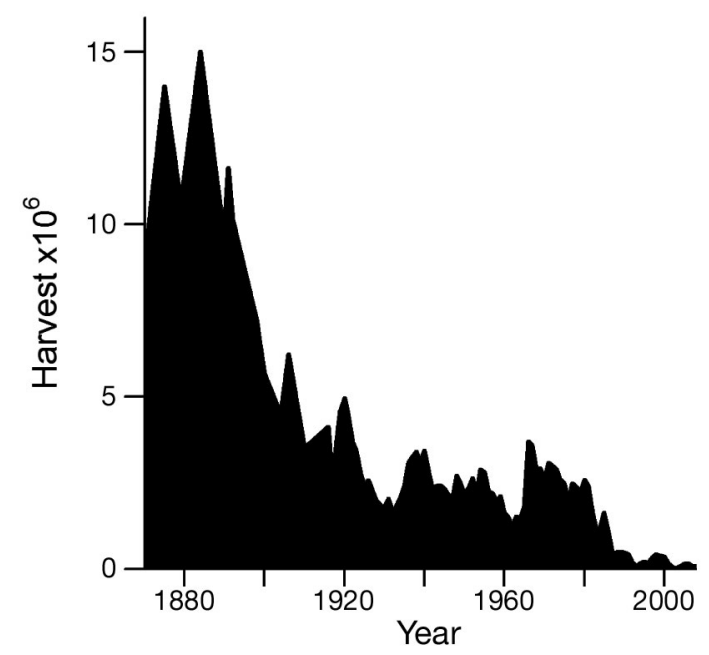

Fig. 1. Crassostrea virginica. Reported harvest of Chesapeake Bay oysters (in Maryland bushels) in Maryland and the Potomac River, USA, during 1870 to 2008 and was the largest fishery in the US (Kennedy \& Breisch 1983, Kirby 2004). Harvests rapidly declined during the early 1900s and have been at very low levels since the late 1980s. MSX and Dermo became problematic in Chesapeake Bay in the 1950s and 1960s. Prior to the mid-1980s, these diseases were largely restricted to the high salinity regions of Chesapeake Bay (Burreson \& Ragone Calvo 1996). During 1986 and 1987, Dermo expanded to areas where it had not been previously problematic and caused widespread mortality in Maryland waters of Chesapeake Bay (Andrews 1988, Burreson \& Ragone Calvo 1996), while MSX, despite fluctuating from year to year, largely remained restricted to high salinity regions (Tarnowski 2007).

Despite the large-scale decline, the overall status of the oyster population is not well known. The effects of fishing and disease on the population are not well quantified, and during the last 2 decades, reports of the population's status, near $1 \%$ of virgin abundance, have remained relatively unchanged (Newell 1988, Jackson et al. 2001, Maryland Department of Natural Resources [DNR] 2009). Under the stresses of continued fishing, disease, and habitat loss, harvests declined $>95 \%$ between 1980 and 2008. Habitat area and quality have also declined since the early 1800s (Rothschild et al. 1994, Hargis \& Haven 1999, Smith et al. 2005), but the current status of available habitat is uncertain. We applied a novel population dynamics model to facilitate science-based management of Maryland's oyster resource. The model included live and articulated valves of recently dead individuals (commonly called boxes) to estimate changes in abundance, fishing and natural mortality, and habitat of oysters in upper Chesapeake Bay.

\section{MATERIALS AND METHODS}

Data. Maryland DNR has conducted a fall dredge survey to monitor eastern oysters in Maryland waters of Chesapeake Bay annually since 1939, but only data for young-of-the-year (YOY) are available before 1980. The fall dredge survey samples between 200 and 400 oyster reefs per year (Jordan et al. 2002). A dredge is towed on suitable oyster habitat, a half-bushel subsample of material brought up in the dredge (cultch) is taken, and oysters are counted and classified into 3 size-age categories: YOY, small ( $\geq 1 \mathrm{yr}$ old, $<76 \mathrm{~mm}$ shell height), and market ( $\geq 76 \mathrm{~mm}$ shell height) (Tarnowski 2007). Oysters in the small and market size categories are considered adults. In addition, boxes by size-age category are also counted, but YOY boxes are rarely observed. The number of oysters and boxes in each category were recorded as number per bushel of 
cultch material. Oyster shell predominates the cultch material. Vessels and dredges used in the survey changed during 1980 to 2008. The survey was conducted by the RV 'Aquarius' during 1980 to 1982, the RV 'Discovery' during 1983 to 1984 , and the RV 'Miss Kay' during 1985 to 2008 (M. Tarnowski, Maryland DNR, pers. comm.). The first 2 vessels likely had their own dredges, and the dredge used on the RV 'Miss Kay' was changed in 2001 to 2002 and in 2008. All the dredges used on the RV 'Miss Kay' had the same width $(0.81 \mathrm{~m})$ and similar weight (M. Tarnowski, Maryland DNR, pers. comm.).

Harvest was reported by dealers who bought the oysters from fishermen in Maryland and is reported by both dealers and fishermen in the Potomac River. Commercial oyster fishermen suggested in conversations with Maryland DNR scientists that $\sim 50 \%$ of the harvest was reported each year, and we used this value to correct reported harvest (M. Naylor, Maryland DNR, pers. comm.). The estimated reporting rate contains substantial unquantifiable uncertainty because it is based on anecdotal reports by fishermen. To investigate the consequences of this uncertainty, we conducted sensitivity analyses using 40 and $60 \%$ reporting rates. Because oyster dealers must pay a 'bushel tax' of $\$ 1$ per bushel reported harvest, the reporting rate is likely to be $<100 \%$. We assumed 350 marketsized oysters bushel ${ }^{-1}$ on average (North et al. 2010).

Standardizing indices of density. We developed standardized indices of density per unit habitat area from the catch of YOY, small, and market-sized live oysters and small and market-sized boxes per bushel of cultch in Maryland DNR's fall dredge survey on all reefs that were sampled more than once during 1980 to 2008. Previous studies have shown that dredge survey catches provide a local index of density (i.e. catches are proportional to abundance per unit area) instead of absolute density estimates (Chai et al. 1992, Mann et al. 2004, Powell et al. 2007) and that the catchability of the dredge survey is likely reef specific, but does not vary over time for a given reef (Powell et al. 2007). However, the Maryland DNR dredge survey was conducted differently than other dredge surveys. Briefly, 2 issues confound simple interpretation of the Maryland DNR dredge survey data: (1) sampling is not random in that it only occurs on oyster habitat, and (2) the unit of measure is number per bushel of cultch material instead of number per tow or number per tow area as are commonly used. We interpret the dredge catch per bushel of cultch as an index of density per unit habitat area (i.e. to indicate trends in density on oyster habitat over time) because the dredge collects both individuals and their habitat. For the dredge survey to represent an index of density per habitat area, catchability of cultch and live oysters should be, on average, constant over time (i.e. not have trends over years). However, the survey can have different catchabilities for cultch and live oysters, as was found by Powell et al. (2007), and still represent an appropriate index of density. To test for potential changes in catchability caused by changes in survey vessels or dredges, we conducted a sensitivity analysis that estimated a different catchability coefficient for each vessel, dredge, and sizecategory combination and evaluated evidence of time-varying catchability using Akaike's Information Criterion (AIC) (Burnham \& Anderson 2002). The time blocks for different catchability parameters were 1980 to 1982,1983 to 1984,1985 to 2002, and 2003 to 2008. We were unable to test for a change in catchability in 2008 because multiple years of data were necessary to statistically estimate each catchability parameter. In addition, because the survey is conducted only on known oyster habitat, it only reflects trends in density in areas with good habitat. Thus, trends in catch rates must be corrected for changes in the area of habitat to provide an index of abundance.

To standardize the indices of density, we used a generalized linear model (McCullagh \& Nelder 1989), which included a negative binomial distribution and a log link function, to correct for changes in sites sampled among years and differences in catchability among sites. Indices of density were developed separately for each stage. The model included effects for site and year (treated as class variables):

$$
E\left[\log _{\mathrm{e}}\left(C_{\text {year,site }}\right)\right]=\alpha+\beta_{\text {year }}+\gamma_{\text {site }}
$$

where $E\left[\log _{\mathrm{e}}\left(C_{\text {year,site }}\right)\right]$ is the expected value of $\log$ catch $(C)$ for a given year and site, $\alpha$ is the intercept, $\beta$ is a categorical year effect, and $\gamma$ is a site effect. The standardized index of density on the log scale for each year and stage was provided by the sum of the year effect and intercept. The negative binomial distribution is commonly used for over-dispersed count data, and a log link function is commonly recommended for this type of model (McCullagh \& Nelder 1989). The indices of density covered 1980 to 2008.

Model description. We applied our model to eastern oysters in upper Chesapeake Bay (Maryland and the Potomac River) to estimate abundance, effects of fishing and disease on the population, and changes in habitat area during 1980 to 2009. The model included effects of fishing and time-varying natural mortality, and was stage-structured with stages for YOY, small, and market-sized live oysters and small and marketsized boxes. Abundance in each stage changed due to growth, fishing mortality, natural mortality, and recruitment. Natural mortality includes all non-fishing sources of mortality (e.g. disease, predation). The model also tracked the number of boxes, which pro- 
vided information on natural mortality for small and market sizes. Model parameters were simultaneously estimated by fitting the model to the dredge survey indices of density subject to the constraints of the catch time series (Hilborn \& Mangel 1997). Thus, the model integrates the survey and catch time series, but most of the information about population size is from the catch time series. Variables included in the model are described in Table 1.

Annual recruitment (number of YOY oysters in fall) was estimated as a model parameter. The number of small oysters $(N)$ was the sum of YOY that survived the year and the number of small oysters that survived but remained small (see variable definitions in Table 1):

$$
N_{y+1,1}=N_{y, 0} \mathrm{e}^{-M_{0}}+(1-G) N_{y, 1} \mathrm{e}^{-M_{y, 1}}
$$

The transition probability from small to market size $(G)$ was estimated, and the instantaneous natural mortality rate $(M)$ for YOY was assumed to be $0.7 \mathrm{yr}^{-1}$ (annual rate of $\sim 50 \% \mathrm{yr}^{-1}$ ), based on estimated mortality of stocked oysters from sanctuaries and managed reserves in Mary-

Table 1. Symbols in Maryland Bay-wide oyster stock assessment model. YOY: young of the year oysters

\begin{tabular}{|c|c|c|}
\hline Variable & Description & Value \\
\hline$y$ & Year & $1980-2009$ \\
\hline$s$ & Stage & $\begin{array}{l}\text { 0: YOY, 1: small, } \\
\text { 2: market }\end{array}$ \\
\hline \multicolumn{3}{|c|}{ Specified quantities } \\
\hline$H$ & Harvest & Fig. 1 \\
\hline $\mathrm{X}$ & Observed index of density & Fig. 2 \\
\hline$r$ & Proportion female (small and market) & $0.3,0.5$ \\
\hline$f$ & Fecundity (millions of eggs; small and market) & 15,35 \\
\hline$u_{0}$ & Exploitation rate prior to 1980 & 0.5 \\
\hline$D$ & Decay rate for articulated shells (small, market) & $0.52,0.45$ \\
\hline$\sigma$ & Log-scale SD & See text \\
\hline$n$ & Number of years & See text \\
\hline$\mu$ & Median of prior for natural mortality & See Table 2 \\
\hline \multicolumn{3}{|c|}{ Estimated quantities } \\
\hline$N$ & Abundance & Estimated \\
\hline$E$ & Egg production & Estimated \\
\hline$M$ & Natural mortality rate (YOY, small, market) & $\begin{array}{l}0.7 \text {, estimated for } \\
\text { small and market }\end{array}$ \\
\hline$G$ & Transition probability from small to market & Estimated \\
\hline$H a b$ & Relative habitat & Estimated \\
\hline$B$ & Abundance of articulated shells & Estimated \\
\hline$u$ & Exploitation rate & Estimated \\
\hline$q$ & Catchability & Estimated \\
\hline$d$ & Instantaneous rate of habitat decline & Estimated \\
\hline$\hat{X}$ & Predicted index of density & Estimated \\
\hline$L$ & Log likelihood component & Estimated \\
\hline$P$ & $\begin{array}{l}\text { Prior for natural mortality and transition } \\
\text { probability }\end{array}$ & Estimated \\
\hline$\alpha$ & Slope of the stock-recruitment relationship & Estimated \\
\hline$\delta$ & $\begin{array}{l}\text { Proportional deviation form median estimated } \\
\text { recruitment }\end{array}$ & Estimated \\
\hline
\end{tabular}

land (Paynter 2007). This value is also consistent with a long-term study in the James River, Virginia, USA, (Mann et al. 2009b). We assumed that the mortality rate of YOYs would be constant on average over time because they are rarely affected by Dermo disease (caused by Perkinsus marinus), which is thought to be the primary source of disease mortality in Maryland waters of Chesapeake Bay (Burreson \& Ragone Calvo 1996), although they may be affected by MSX. Separate natural mortality rates for small-sized oysters were estimated during model fitting for the 1980 to 1985 and 1986 to 2008 periods. We chose 1986 as a break point because of the expansion of Dermo disease throughout Maryland waters of Chesapeake Bay at that time (Burreson \& Ragone Calvo 1996).

The number of market-sized oysters was the sum of small oysters that grew to market size and marketsized oysters that survived natural mortality and harvest $(H)$ (Table 1$)$ :

$$
N_{y+1,2}=G N_{y, 1} \mathrm{e}^{-M_{y, 1}}+N_{y, 2} \mathrm{e}^{-M_{y, 2}}-H_{y}
$$

$M$ was estimated annually for market-sized oysters by allowing annual deviations from median $M$ for all years except 1980. Separate median values of $M$ were estimated for 1980 to 1985 and 1986 to 2008. The first year of the model was fixed at the 1980 to 1985 median because it was used in the equilibrium calculations to calculate abundance for each stage in the first year. The model specified that natural mortality occurs before growth and all natural mortality and growth occur before the fishing season. Growth and most mortality from disease occur during summer and early autumn (Andrews 1988, Vølstad et al. 2008), whereas harvest occurs from October to March. We tested a preliminary version of the model in which growth occurred before natural mortality, but the change made very little difference in model estimates. We estimated egg production each year to plot the stockrecruitment relationship as the product of abundance and the stage-specific fecundity $(f)$ and sex ratio $(r)$ (Table 1$)$ (North et al. 2010):

$$
E_{y}=\sum_{s} N_{y, s} r_{s} f_{s}
$$

The model tracked the number of boxes $(B)$ in small and market cate- 
gories. Within a size category, the number of boxes is calculated as the sum of new boxes from natural mortality in the population and old boxes that still remain from natural decay $(D)$ and destruction by fishing in previous years (Table 1):

$$
B_{y+1, s}=N_{y, s}\left(1-\mathrm{e}^{-M_{y, s}}\right)+B_{y, s} \mathrm{e}^{-D_{s}}\left(1-u_{y}\right)
$$

We used estimates from Maryland waters of Chesapeake Bay of instantaneous decay rates of $0.45 \mathrm{yr}^{-1}$ for market and $0.52 \mathrm{yr}^{-1}$ for small categories (Christmas et al. 1997).

We defined exploitation rate $(u)$ as the percentage of the market-sized population available at the beginning of the fishing season that was harvested annually (Table 1):

$$
u_{y}=\frac{H_{y}}{G N_{y, 1} \mathrm{e}^{-M_{y, 1}}+N_{y, 2} \mathrm{e}^{-M_{y, 2}}}
$$

We modeled relative habitat area as an exponential decline since 1980 (Table 1):

$$
H a b_{y}=\mathrm{e}^{-d(y-1980)}
$$

The model required a method to estimate abundance for small and market-sized oysters and boxes in 1980 . The initial abundances in 1980 of small and marketsized oysters, both alive and boxes, were calculated using indices of YOY density during 1970 to 1979. The abundance of YOY oysters during this period was calculated by multiplying index of density of YOYs by their catchability $(q)$. The number of small and marketsized oysters and boxes was calculated by applying the population dynamics equations with an assumed exploitation rate of $50 \%$ for years prior to 1980 (Jordan et al. 2002). Our implementation assumed that during 1970 to 1979 , oysters experienced the same natural mortality as was estimated for 1980. We used this approach to avoid assuming constant recruitment before 1980, but still assumed constant mortality rates.

Predicted indices of density $(X)$ were estimated in the model as the product of catchability and abundance scaled by relative habitat area (Table 1):

$$
\begin{gathered}
\hat{X}_{N, Y, 0}=q_{N, 0} N_{y, 0} / H a b_{y} \\
\hat{X}_{N, Y, 1}=q_{N, 1}(1-G) N_{y, 1} \mathrm{e}^{-M_{y, 1}} / H a b_{Y} \\
\hat{X}_{N, Y, 2}=q_{N, 2}\left(G N_{y, 1} \mathrm{e}^{-M_{y, 1}}+N_{y, 2} \mathrm{e}^{-M_{y, 2}}\right) / H a b_{Y} \\
\hat{X}_{B, Y, s}=q_{B, s}\left[N_{Y, s}\left(1-\mathrm{e}^{-M_{y, s}}\right)+B_{Y, s}\right] / H a b_{y}
\end{gathered}
$$

where the index of density of live oysters or boxes occurs just before the beginning of the fishing season, but after growth and natural mortality. Abundance in small and market-sized categories represented abun- dance in the middle of the summer, and abundance of YOY oysters represented abundance in the fall just prior to the beginning of the fishing season. Thus, indices of density were corrected for growth and mortality that occurred between the beginning of the model year and the time of the survey. For YOY, the index of density includes both those produced in the wild and in hatcheries because the survey occurs after stocking, but the model does not estimate the proportion from stocked sources. Catchability was calculated using the maximum likelihood estimate (Table 1):

$$
\log _{\mathrm{e}} q_{X, s}=\frac{\sum_{y}\left[\log _{\mathrm{e}}\left(X_{Y, s} / N_{Y, s}\right)\right]}{n}
$$

YOY abundance was estimated as individual parameters for each year. The model estimated the transition probability from small to market-sized oysters. To estimate density and area of available habitat, we started with the area of high quality habitat from the Maryland Bay Bottom Survey (MBBS; cultch and sand with cultch categories, $668 \mathrm{~km}^{2}$ ) in 1980 (Smith et al. 2001). Habitat area each year was the product of relative habitat and habitat area in 1980.

We used a Bayesian approach for parameter estimation (Gelman et al. 2004), and the model was fitted to oyster relative density data from the Maryland DNR fall dredge survey and harvest estimates. The model was developed in AD Model Builder and parameters were estimated using Markov Chain Monte Carlo (MCMC) with a Metropolis-Hastings algorithm. Three parallel MCMC chains were run for 1000000 steps, and were thinned by saving every 200th step. We removed the initial 200000 steps of each chain as a burn-in (Gelman et al. 2004). Convergence was determined using Gelman-Rubin plots (Brooks \& Gelman 1998), Geweke plots (Geweke 1992), and visual inspection of the chains of the parameters.

The objective function contained lognormal likelihood components $(L)$ for market, small, and wild spat category live oysters and market and small boxes (Table 1):

$L_{X, s}=n \log _{\mathrm{e}}\left(\sigma_{X}\right)+\frac{1}{2 \sigma_{X}^{2}} \sum_{y=1980}^{2008}\left[\log _{\mathrm{e}}\left(X_{Y, s}\right)-\log _{\mathrm{e}}\left(\hat{X}_{Y, s}\right)\right]^{2}$

The constants in the likelihood function and priors were ignored for simplicity. The assumed standard deviations $(\sigma)$ on the $\log _{\mathrm{e}}$ scale for these data sources were 1.0 for spat, 0.4 for small, 0.3 for market, 0.5 for small boxes, and 0.4 for market boxes. These values represent the relative ability of the dredge to sample the different size classes and for individuals to be identified within the samples. They are also consistent with the residual variance of the model fits to the data series. 
Estimated parameters included recruitment for each year, natural mortality for small and market-sized oysters, the transition probability from small to market size, catchability for each index of density, and the rate of decline of habitat area (Table 1). Lognormal priors $(P)$ were specified for the median natural mortality rate parameters (Tables 1 \& 2):

$$
P_{s}=\log _{\mathrm{e}}\left(\sigma_{s}\right)+\frac{1}{2 \sigma_{s}^{2}}\left[\log _{\mathrm{e}}\left(\mu_{s}\right)-\log _{\mathrm{e}}\left(M_{s}\right)\right]^{2}
$$

We assumed that annual deviations in natural mortality for market-sized oysters followed a lognormal distribution with a log-scale standard deviation of 0.5 . This allows substantial annual variation in natural mortality. The model contained a lognormal prior on the transition probability from small to market size class, with a median of 0.45 based on growth in sanctuaries in Maryland waters of Chesapeake Bay and a log-scale standard deviation of 0.3 (Paynter et al. 2010). All other parameters had uniform priors. The overall objective function was the sum of the log likelihood components for each data source and the priors.

We estimated credibility intervals (CI), the Bayesian analog of a confidence interval, for model estimates (Gelman et al. 2004). A $90 \%$ CI indicates that the true value has a $90 \%$ probability of being within the interval. We constructed $90 \%$ CIs as the range between the 5th and 95th percentiles of the posterior distribution.

Virgin abundance. We estimated virgin adult abundance (i.e. abundance before the onset of commercial fishing), the decline in adult abundance from virgin levels to 2009, and the uncertainty in these values using a Monte Carlo simulation. Virgin adult abundance was the product of habitat prior to fishing and adult oyster density. Bounds on the virgin area of oyster habitat can be estimated from the area of all categories considered oyster habitat in the MBBS (oyster shell, shell with sand, and shell with mud). The area of

Table 2. Prior distributions of parameters. U: uniform distribution with lower and upper bounds. LN: lognormal distribution with the log median parameter and log-scale SD. Variables: see Table 1

\begin{tabular}{|ll|}
\hline Parameter & Prior distribution \\
\hline $\log _{\mathrm{e}}($ mean recruitment) & $\mathrm{U}(0,20)$ \\
$G$ & $\mathrm{LN}\left[\log _{\mathrm{e}}(0.45), 0.3\right]$ \\
$\log _{\mathrm{e}}$ (recruitment deviations) & $\mathrm{U}(-10,10)$ \\
$M_{\mathrm{y}, 1}$ & $\mathrm{LN}\left[\log _{\mathrm{e}}(0.3), 0.5\right]$ for $y<$ \\
& $1986 \mathrm{LN}\left[\log _{\mathrm{e}}(0.65), 0.5\right]$ for \\
$M_{\mathrm{y}, 2}$ & $y \geq 1986$ \\
& $\mathrm{LN}\left[\log _{\mathrm{e}}(0.15), 0.5\right]$ for $y<1986$ \\
$\log _{\mathrm{e}}$ market $M$ deviations & $\mathrm{LN}\left[\log _{\mathrm{e}}(0.6), 0.5\right]$ for $y \geq 1986$ \\
$d$ & $\mathrm{LN}(0,0.5)$ \\
& $\mathrm{U}(0,2)$ \\
\hline
\end{tabular}

these categories combined $\left(885 \mathrm{~km}^{2}\right)$ provides an upper bound on virgin habitat because dredging since the late 1800 s decreased the vertical relief of reefs while spreading the shell over a larger area (Kennedy $\&$ Breisch 1983). The area of the shell category $\left(478 \mathrm{~km}^{2}\right)$ likely provides a minimum estimate on the amount of virgin habitat because oyster reefs were regarded as degraded by 1975 to 1983 when the MBBS was conducted (Rothschild et al. 1994). Mann et al. (2009a) estimated that the minimum precolonial oyster density necessary for oyster reef accretion to keep pace with rising sea levels ranged from 64 to 154 oyster $\mathrm{m}^{-2}$, depending on the assumed longevity of oysters. These estimates are substantially lower than average adult density estimates from contemporary unfished reefs in South Carolina during 1970 to 1972 , $874 \mathrm{~m}^{-2}$ (Dame 1976) and Chesapeake Bay, $683 \mathrm{~m}^{-2}$ (Schulte et al. 2009). To estimate virgin abundance and allow for the large amount of uncertainty in this estimate, we simulated virgin habitat and density from uniform distributions with lower and upper bounds of 478 to $885 \mathrm{~km}^{2}$ for habitat (Smith et al. 2001) and 65 to 874 oysters $\mathrm{m}^{-2}$ for adult density (Dame 1976, Mann et al. 2009a). We estimated the decline from virgin levels by dividing a random draw from the posterior distribution of adult abundance in 2009 by the simulated virgin abundance. Our simulation approach to estimate virgin abundance and amount of population decline by 2009 assumed that the distributions of abundance in 2009 and virgin density and habitat are independent, which should be valid given that different data sets were used to inform each component. We used 12000 random draws in the simulation.

Projections. We conducted 2 projections to compare the effects of fishing and the expansion of Dermo disease on the population. The projections used the same equations as the stock assessment model to project abundance of small and market stages and egg production each year until 2009 except that the fishing and natural mortality rates were altered. The harvest was set to zero after 1985 to evaluate effects of fishing, and natural mortality for small and market sizes after 1985 was set to the mean from 1980 to 1985 . The projection used a linear stock-recruitment relationship with proportional errors $\left(\delta_{y}\right)$ equal to those from the population model to predict recruitment each year:

$$
N_{y, 0}=\alpha E_{y} \delta_{y}
$$

where $\alpha=0.069$ was the slope of the relationship. Proportional errors in recruitment each year were estimated as the quotient of the median estimate of recruitment and predicted recruitment from the linear model. A linear stock-recruitment relationship is reasonable for this stock because abundance is very low (Myers et al. 1999). 
Sensitivity analyses. We conducted sensitivity analyses to determine the effect of some of the important assumptions on the model results. These included assuming that (1) the number of oysters per bushel was 275 or 425 , (2) the proportion of unreported catch was 40 or $60 \%$, (3) the log-scale standard deviation of the indices of abundance were all equal to 0.4 , (4) the instantaneous rate of decay for boxes was 1.03 (Ford et al. 2006), (5) the instantaneous natural mortality rate for YOYs was 1.4 and 0.35 (+100 and $-50 \%$ respectively), and (6) the mean of the prior for natural morality for small and market stages was $\pm 20 \%$ of the base values. Each change was evaluated individually. To assess the sensitivity of the model to these changes, we compared estimates of adult abundance in 2009, change in adult abundance between 1980 and 2009 (depletion), average recruitment, average natural mortality rate during 1980 to 1985 and 1986 to 2008 for small and market size categories, relative habitat in 2009, and average exploitation rate during 1980 to 2008 to those from the base model.

\section{RESULTS}

Median model estimates of relative density fit the observed data reasonably well and showed the patterns of overall decline for all live stages, and 2 peaks for boxes (Fig. 2). The best fits were obtained for relative density of market-sized boxes and live oysters (Fig. 2A,B). Some residual pattern was present in the fits to indices of density for small boxes, live oysters and YOY (Fig. 2C-E). Small and YOY oysters showed opposite patterns, with small oysters being underestimated in the beginning and end of the time series and YOY being overestimated during the same periods. This residual pattern was potentially caused by natural mortality rates varying over time, which we were not able to include in the model for YOY and small stages due to data limitations. Among live oyster size categories, catchability was lowest for YOYs (0.0002 with $90 \%$ CI: 0.0001 to 0.0003$)$, followed by small (0.011, 0.006 to 0.021$)$, and market-sized individuals $(0.023$, 0.016 to 0.031$)$. Small boxes had lower catchability $(0.002,0.006$ to 0.021$)$ than market boxes $(0.012,0.006$ to 0.022 ).

The median estimate of adult oyster abundance (small and market categories) in 2009 was 851 million (90\% CI: 354 million to 2630 million; Fig. 3A). Our median estimate of virgin adult abundance was 311 billion (68 billion to 622 billion). Compared to our estimate of virgin adult abundance, the population has declined $99.7 \%$ (98.3 to $99.9 \%$ ). During 1980 to 2009 , adult abundance declined $92 \%$ (84.6 to $94.7 \%$ ) at a rate of $7.7 \% \mathrm{yr}^{-1}$, although a strong 1997 year class

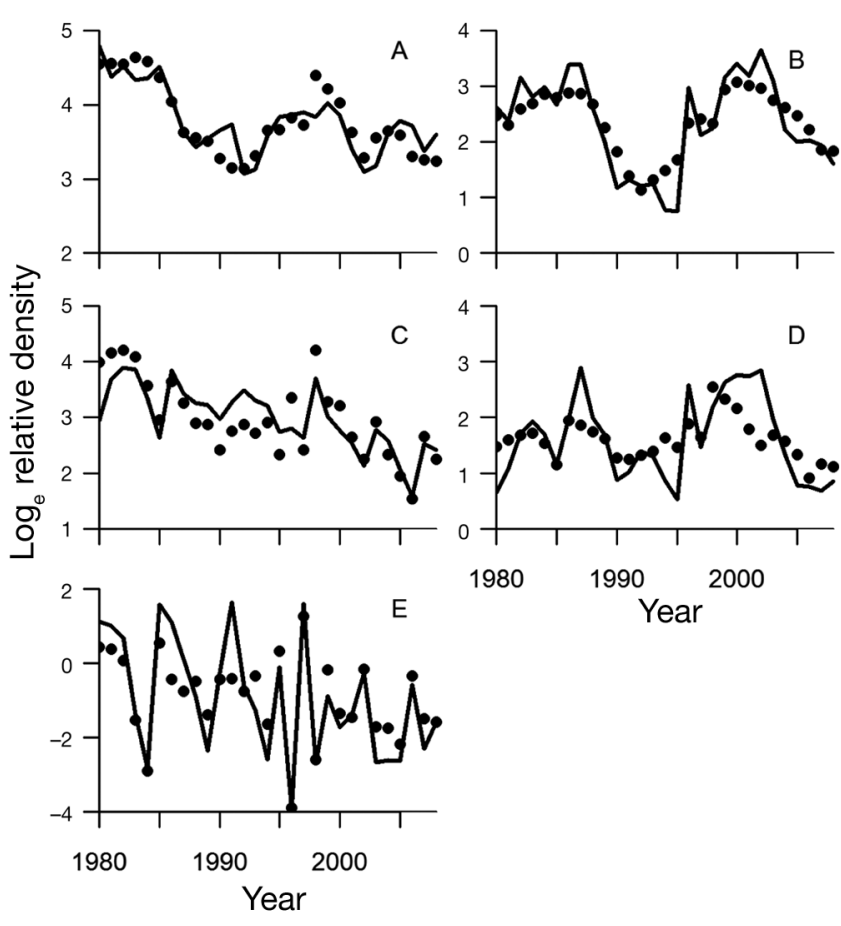

Fig. 2. Crassostrea virginica. Observed (points) and predicted (lines) indices of density (on the $\log _{e}$ scale) for (A) marketsized, (B) market-sized articulated valves, (C) small, (D) small articulated valves, and (E) young-of-the-year (YOY). Predicted values indicate the mode of the posterior distribution

provided some relief from the downward trend. The rate of decline increased in the latter part of the time series, with $12 \% \mathrm{yr}^{-1}$ from 2000 onwards. The median estimate of the transition probability from small to market size classes was 0.3 (0.21 to 0.42$) \mathrm{yr}^{-1}$. Recruitment varied interannually with relatively strong year classes during 1980 to 1982, 1985, and 1997, but has been extremely low since 1998 (Fig. 3B). Expected recruitment generally increased with increasing stock size, but there was a large amount of variability about the relationship and the largest year class was produced when stock size was low (Fig. 4). Habitat area declined by $4.1 \% \mathrm{yr}^{-1}$ to $31 \%$ (20 to $68 \%$ ) of the 1980 level during the last 3 decades (Fig. 3C).

Natural mortality of market-sized oysters varied between 15 and $59 \% \mathrm{yr}^{-1}$ and averaged $27 \% \mathrm{yr}^{-1}$ prior to the Dermo disease expansion in 1986 and 1987, doubled during 1986 to 1987 due to increased levels of disease, and fell to lower levels thereafter except during 1999 to 2002 . For small oysters, the average natural mortality rate increased from $17 \%$ (90\% CI: 11 to $27 \%$ ) $\mathrm{yr}^{-1}$ during 1980 to 1985 to $37 \%$ (28 to $49 \%$ ) $\mathrm{yr}^{-1}$ during 1986 to 2008. Exploitation rate varied between 3 and $51 \% \mathrm{yr}^{-1}$ and averaged $25 \% \mathrm{yr}^{-1}$ during 1980 to 2008 (Fig. 5A). The exploitation rate declined during 1980 to 2003 and increased since 2003 to $20 \% \mathrm{yr}^{-1}$. During 1980 to 1992 , exploitation and natural mortality rates 

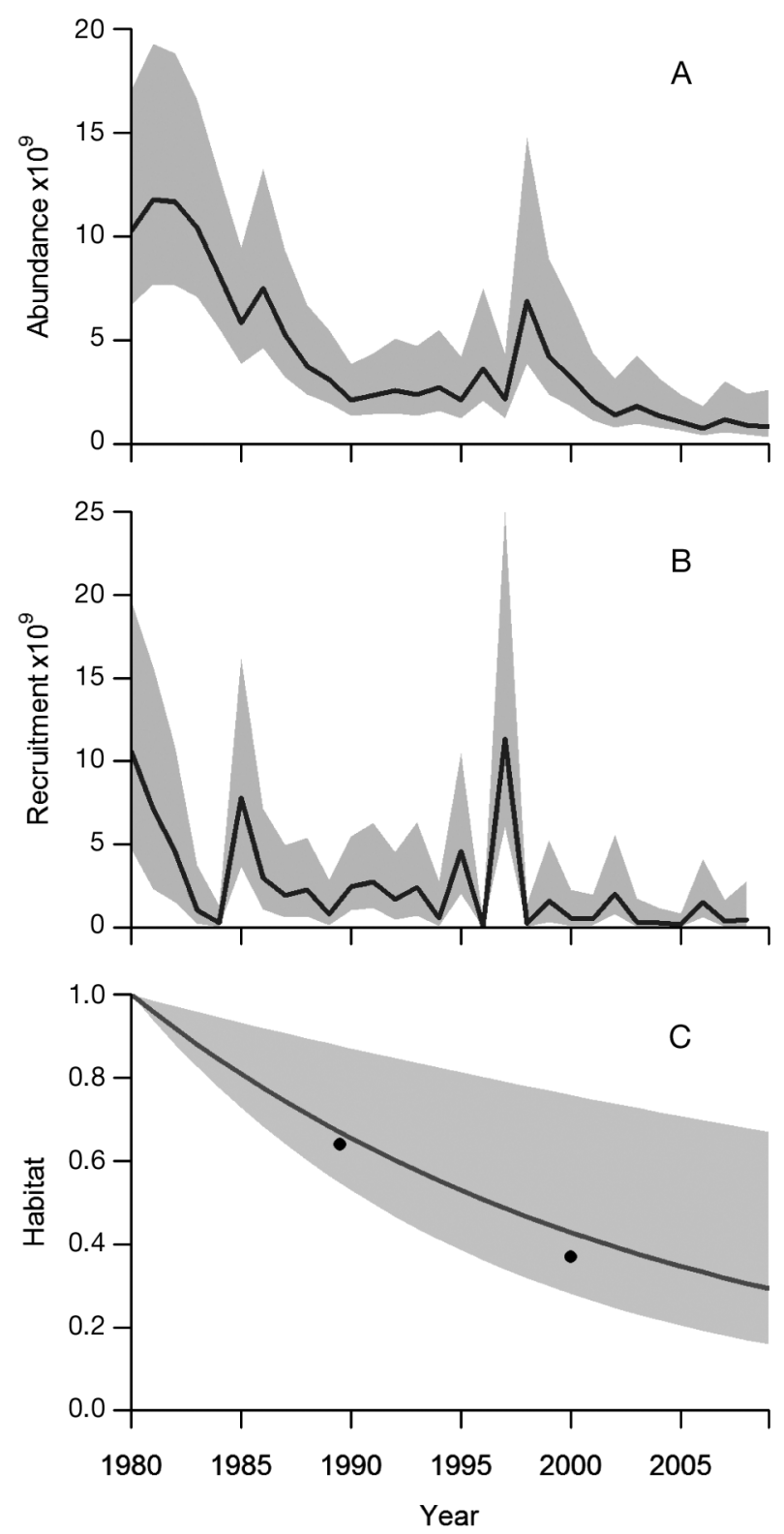

Fig. 3. Crassostrea virginica. Changes in (A) adult abundance, (B) young of the year (YOY) (recruitment) abundance, and (C) relative habitat during 1980 to 2009. (C) Points: independent estimates from Rothschild et al. (1994) and Smith et al. (2005). Solid lines: median posterior estimates. Shaded regions: $90 \%$ credibility intervals (CI)

for market-sized oysters were approximately equal, but natural mortality exceeded the exploitation rate in most years since 1992 .

Most of the estimates from the model were not sensitive to the assumptions evaluated in the sensitivity analyses (Table 3). Average YOY abundance was the most sensitive result to changes in model assumptions. In particular, average YOY abundance was sensitive to the assumed natural mortality rate during the first

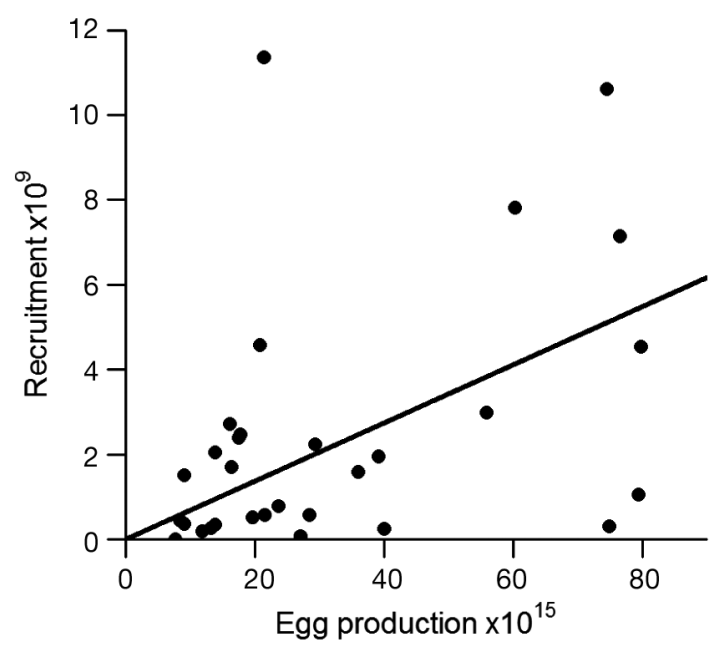

Fig. 4. Crassostrea virginica. Relationship between median estimated recruitment and egg production. Points: model estimates. Lines: best fit linear model through the origin
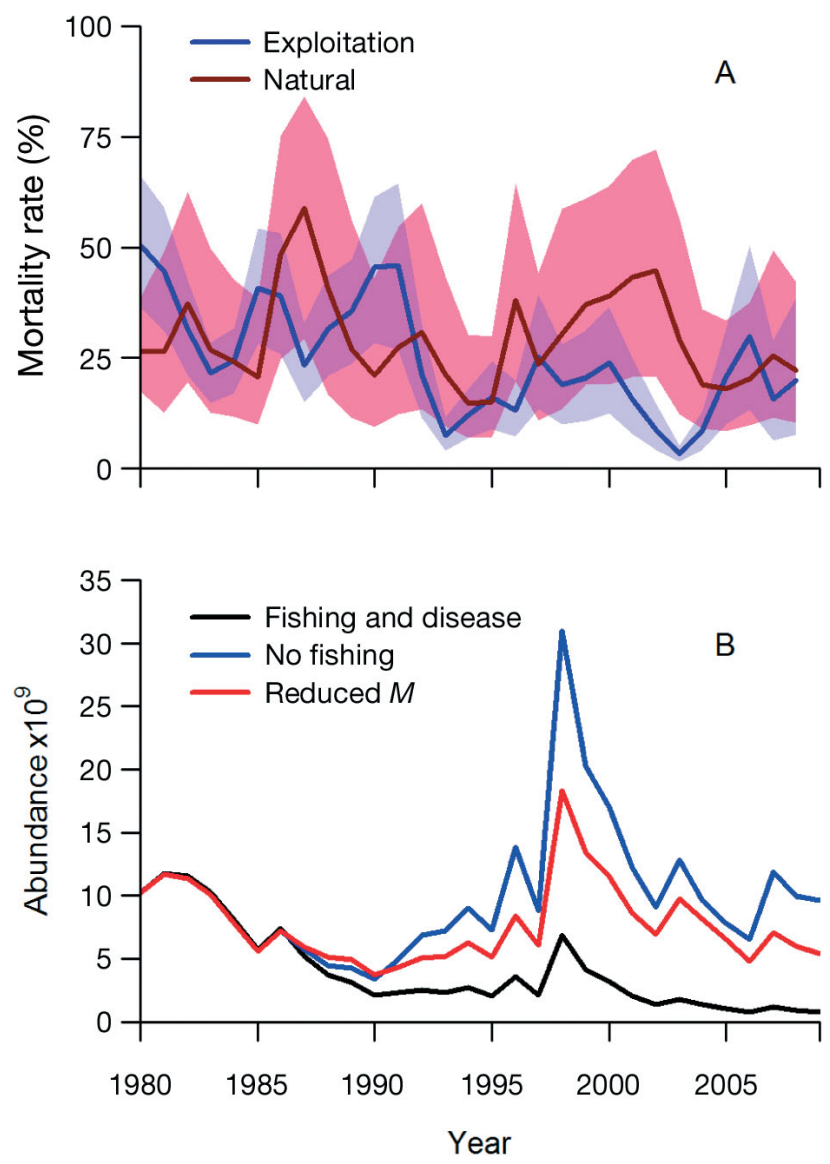

Fig. 5. Crassostrea virginica. (A) Annual natural mortality and exploitation rates for market-sized oysters. Solid lines: median posterior estimates. Shaded regions: $90 \%$ credibility intervals (CI). (B) Projected adult abundance during 1980 to 2008 with fishing and disease; without fishing, and no disease ('No fishing'); and without disease but with fishing (Reduced $M$ ) 
year. The natural mortality rates were the least sensitive estimates, usually differing by $<10 \%$ from the base case. The scenario that had the largest change from the base across most variables was the time-varying catchability. While estimates from the time-varying catchability model were substantially different from the base model, the AIC difference of 17.9 (AIC weight $<0.001$ ) indicated essentially no support for the timevarying catchability model (Burnham \& Anderson 2002).

Fishing has had a greater effect on oysters than increasing natural mortality since 1986 (Fig. 5B). Projections show that under the single stress of increased $M$ or fishing, the population would have maintained itself at substantially higher levels than those which actually occurred. Compared to current conditions, if fishing had ceased in 1986, adult abundance would have been 15.8 times greater in 2009. If natural mortality had not increased, adult abundance would have been 8.9 times greater than the 2009 estimate. Adult abundance was predicted to increase under the no fishing scenario and was maintained under the reduced $M$ scenario. However, adult abundance still would have shown substantial fluctuations in the absence of fishing or expansion of Dermo.

\section{DISCUSSION}

The oyster population in upper Chesapeake Bay is at an extremely low abundance, and fishing mortality continues to be substantial. The natural mortality rate is often considered an upper limit on the rate of sustainable fishing (Williams \& Shertzer 2003). For oysters, however, the sustainable fishing mortality rate is thought to be substantially less than natural mortality because oyster shells provide habitat for the next generation (Powell \& Klinck 2007). Powell \& Klinck (2007) estimated that an exploitation rate of $7 \% \mathrm{yr}^{-1}$ would be sustainable for Delaware Bay oysters. The exploitation rate in upper Chesapeake Bay has exceeded $7 \%$ in almost all years since 1980. The maximum sustainable exploitation rate may be $<7 \%$ because Powell \& Klinck (2007) did not include direct effects of fishing on habitat, which can be substantial (Lenihan \& Peterson 1998, 2004). Additionally, increased disease mortality also reduces the sustainable fishing mortality rate (Mann \& Powell 2007).

The Chesapeake 2000 Agreement set a target of a 10-fold increase in oyster abundance from 1994 levels by 2010 (EPA 2000). Abundance in 2009 was only $31 \%$ of the 1994 reference level and $27 \%$ of the 2000 level when the goal was adopted. The target from the Chesapeake 2000 Agreement was not achieved by 2010; even more troubling, the population has continued to decline since the agreement. Additionally, our estimate of current abundance is $0.3 \%$ of the virgin level, substantially lower than the $1 \%$ commonly used in policy discussions (e.g. Maryland DNR 2009). This revised estimate highlights the substantial decline in oyster abundance since the 1980 s and will be an important consideration as policies for restoring oysters in Chesapeake Bay are developed.

Habitat has declined to an estimated $31 \%$ of the area available in 1980, and our estimated change in habitat is corroborated by 2 other studies. Oyster habitat throughout Maryland waters of Chesapeake Bay was surveyed by the MBBS during 1974 to 1981 (Smith et al. 2001), and changes since the MBBS were estimated

Table 3. Crassostrea virginica. Results of sensitivity analyses for adult abundance $(N)$, depletion, mean recruitment (young of the year: YOY), mean natural mortality $(M)$ for market-sized oysters pre- and post disease, small oysters pre- and post disease (small pre and small post), relative habitat in 2009, and mean exploitation rate $(u)$. Base indicates median posterior estimates from the base model; remaining values indicate percentage differences of median posterior estimates from the base model. Pre: 1980 to 1985; Post: 1986 to 2008; Depletion: abundance of adult population in 2009 relative to 1980

\begin{tabular}{|lccccccccc}
\hline & $\begin{array}{c}2009 \\
\text { adult } N \\
\text { (millions) }\end{array}$ & $\begin{array}{c}\text { Depletion } \\
(\%)\end{array}$ & $\begin{array}{c}\text { Mean } \\
\text { YOY }\end{array}$ & $\begin{array}{c}\text { Market } \\
\text { pre }\end{array}$ & $\begin{array}{c}\text { Market } \\
\text { post }\end{array}$ & $\begin{array}{c}\text { Small } \\
\text { pre }\end{array}$ & $\begin{array}{c}\text { Small } \\
\text { post }\end{array}$ & $\begin{array}{c}\text { Habitat } \\
2009 \\
(\%)\end{array}$ & $\begin{array}{c}\text { Avg. } \\
u(\%)\end{array}$ \\
\hline Base & 851.2 & 8.3 & 2532.9 & 26.9 & 30.3 & 17.0 & 37.4 & 30.7 & 24.7 \\
275 bushel $^{-1}$ & -20.8 & 1.1 & -21.4 & 0.3 & -2.3 & 0.5 & -0.2 & 0.6 & -0.1 \\
425 bushel $^{-1}$ & 22.4 & 1.1 & 21.5 & 0.3 & -2.3 & 0.5 & -0.2 & 0.6 & -0.1 \\
Non-reporting 40\% & -16.0 & 1.1 & -16.6 & 0.3 & -2.3 & 0.5 & -0.2 & 0.6 & -0.1 \\
Non-reporting $60 \%$ & 26.0 & 1.1 & 25.1 & 0.3 & -2.3 & 0.5 & -0.2 & 0.6 & -0.1 \\
Equal CVs, 40\% & -2.5 & 2.6 & 24.6 & 27.6 & 8.7 & -7.3 & -7.1 & 23.0 & -12.9 \\
Hab $M$ (Ford) & 34.7 & 19.7 & 11.6 & -2.4 & 2.8 & -11.0 & -8.4 & 15.6 & -19.7 \\
Spat $M$ 0.35 & 0.8 & 1.1 & -29.5 & 0.3 & -2.3 & 0.5 & -0.2 & 0.6 & -0.1 \\
Spat $M$ 1.4 & 0.8 & 1.1 & 101.5 & 0.3 & -2.3 & 0.5 & -0.2 & 0.6 & -0.1 \\
Prior $M$ (up 20\%) & 6.5 & -1.2 & 10.6 & 6.0 & 2.8 & 8.7 & 3.8 & 2.3 & -3.4 \\
Prior $M$ (down 20\%) & -11.0 & -3.0 & -12.1 & -7.6 & -10.4 & -9.0 & -4.1 & -3.6 & 4.2 \\
Time-varying catchability & 118.7 & 94.9 & 6.1 & -44.0 & 13.4 & 20.9 & -42.8 & 216.5 & -20.1 \\
\hline
\end{tabular}


in 2 smaller scale surveys in 1989 to 1990 (Rothschild et al. 1994) and 1999 to 2001 (Smith et al. 2005). We found a $34 \%$ decline in habitat during 1980 to 1990 compared to a $36 \%$ decline from Rothschild et al. (1994), and a $57 \%$ decline during 1980 to 2000 compared to a $63 \%$ decline from Smith et al. (2005), both of which were within the $90 \%$ CIs of our estimates (Fig. 3C). The quality of habitat has also declined, with most reefs having little vertical relief (Hargis \& Haven 1999) and substantial sedimentation (Smith et al. 2005). The decline in habitat quality and quantity is likely due to a combination of direct removal from harvest, reduction in accretion rates from disease and lack of recruitment, and excessive siltation (Rothschild et al. 1994, Hargis \& Haven 1999, Mann et al. 2009b). Current estimates suggest that average density of adult oysters in the Virginia portion of Chesapeake Bay is between 2 and 11 oysters $\mathrm{m}^{-2}$ (Mann et al. 2009b, Southworth et al. 2010). We found the average density of adults during 2004 to 2009 was 3.7 oysters $\mathrm{m}^{-2}$ habitat. If trends in abundance and habitat since 2000 continue, average adult density will fall to $<1$ oyster $\mathrm{m}^{-2}$ habitat by 2027 and 0.1 oysters $\mathrm{m}^{-2}$ habitat by 2053, and extirpations may occur in wide regions of upper Chesapeake Bay. It is important to highlight that the distribution of oysters is extremely patchy and that density will have high spatial variability even if average density is very low. The total area and quality of habitat continues to decrease, and the historically abundant high-relief oyster reefs are now virtually absent from the Maryland portion of the Chesapeake Bay (Smith et al. 2003). The paucity of high quality habitat is an important limitation for potential oyster population growth and rehabilitation.

Within our modeling framework, we were able to estimate time-varying natural mortality for marketsized oysters. Natural mortality can be difficult to estimate, especially when it changes over time (Patterson 1996). Our model could be applied to other species that have evidence of recent mortality and will be particularly useful when natural mortality is highly variable or trends over time. The increase in natural mortality during 2000 to 2002 coincided with a severe drought and increases in disease prevalence and intensity (Tarnowski 2007). The decline in natural mortality in later years mirrors the decline in disease intensity in Maryland waters, although disease prevalence remains relatively high (Tarnowski 2007). Based on the correspondence of increased natural mortality in times of drought and high disease intensity, we believe that changes in natural mortality after 1986 largely reflect annual variability in disease-induced mortality, although other sources of mortality, such as extended exposure to fresh water, can also be substantial. The model, however, did not explicitly consider spatial pat- terns in disease mortality, which can be spatially and temporally variable (Burreson \& Ragone Calvo 1996, Albright et al. 2007).

Our method of estimating natural mortality was different than typical 'box count' approaches such as those used by Ford et al. (2006) and Vølstad et al. (2008). The traditional method estimates the mortality rate during a period as: boxes/(boxes + live), which assumes that boxes and live oysters have equal catchability, that all oysters that die become boxes, and that all boxes last a certain amount of time (typically $1 \mathrm{yr}$, but see Vølstad et al. 2008). However, our estimates indicated that boxes had lower catchability than live oysters, which was also observed in Delaware Bay (Powell et al. 2007). Lower catchability of boxes than live oysters would cause mortality estimates from traditional box count methods to be consistently underestimated as was found by Mann et al. (2009b). Oyster boxes also may last substantially longer than $1 \mathrm{yr}$ (Christmas et al. 1997). This assumption is especially important when large mortality events occur because a large pulse of boxes will be produced, which may persist in the system for many years. In contrast with the traditional method, our model estimated different catchability for boxes and live oysters, and assumed a constant rate of disarticulation for boxes, so some persisted from one year to the next. Our approach does not specifically estimate the proportion of oysters that die and do not leave boxes because it is subsumed in the catchability parameter. The effect of deaths of oysters that do not leave boxes is likely the cause of the low estimated catchability for small boxes in our study.

While our estimate of virgin abundance contains substantial uncertainty, we believe it is a reasonable approximation based on comparisons with previous studies and historical data. Newell (1988) estimated that the population size in 1988 was $~ 0.9 \%$ of virgin abundance, and our median estimate for the same year was similar at $1.2 \%$ of virgin abundance. Brooks (1905) provided an estimate of the oyster reef area in Maryland waters of Chesapeake Bay of $528 \mathrm{~km}^{2}$ in 1883, but noted that this estimate was 'certainly not excessive' and did not include reefs in the Potomac River, the second largest tributary to Chesapeake Bay. Thus, our mean estimate of the area of virgin oyster habitat $\left(682 \mathrm{~km}^{2}\right)$ was consistent with an independent estimate from the late 1800 s. Our analysis assumed a mean virgin adult oyster density (age 1 and older) of $469 \mathrm{~m}^{-2}$, with a range of 64 to $874 \mathrm{~m}^{-2}$. Early oyster dredge surveys were conducted in Maryland waters of Chesapeake Bay in 1876 and 1883 to 1884 (Brooks 1905), and early harvest estimates are available during the late 1800 s. The surveys found ratios of bushels of oysters to bushels of shell of 3.69 during 1876 and 1.36 during 1882 to 1883 , which indicate a $\sim 64 \%$ decline in density 
between 1876 and 1883 (Brooks 1905). We can derive an estimate of the minimum possible density of oysters in 1884 ( 0.21 bushels $\left.\mathrm{m}^{-2}\right)$ from harvest of 14.5 million bushels and an area of $682 \mathrm{~km}^{2}$. It is difficult to convert bushels to numbers for this period because the number of oysters bushel ${ }^{-1}$ depends on size (North et al. 2010). The average size of oysters in the 1884 harvest should have been less than the modern fishery because no size limit was in place in 1884 and the population was already fully exploited (Kennedy \& Breisch 1983). Assuming a value of 400 to 600 oysters bushel ${ }^{-1}$ (76 mm oysters average about 475 bushel $^{-1}$ ) would place the minimum density in 1884 at 85 to $128 \mathrm{~m}^{-2}$, and 231 to $347 \mathrm{~m}^{-2}$ in 1876 . Because the commercial fishery was already well established by 1876 (Kennedy \& Breisch 1983) and the calculations assume that all adult oysters were harvested in 1884, the estimates of density from that period should underestimate virgin density.

The collapse of eastern oysters in Maryland waters of Chesapeake Bay is among the largest documented declines of a previously widespread marine species, and the magnitude of the decline raises concerns about potential extirpation of this population. We compared Maryland oysters to the status of 162 other fished stocks reviewed in 3 studies: 117 stocks for which stock assessments have been conducted in Worm et al. (2009), 34 diadromous stocks in Limburg \& Waldman (2009), and 11 stocks harvested by the English and Welsh trawl fleet in Thurstan et al. (2010). The decline of oysters (99.7\%) is approximately equal to the largest reported in these studies. The only stock that underwent a larger decrease was Alosa alosa in the Rhine River, The Netherlands, which declined by $99.94 \%$ and was subsequently extirpated (Limburg \& Waldman 2009). Twelve other stocks - 9 from Limburg \& Waldman (2009), Halibut in the UK (Thurstan et al. 2010), and Gulf of Alaska Pacific herring and Atlantic cod in NAFO 3NO (Worm et al. 2009) - declined by approximately the same amount as Maryland oysters (i.e. had declines within the $90 \%$ CI). Like oysters, the stocks in Limburg \& Waldman (2009) were also subject to substantial habitat loss, primarily through damming of river systems. The largest decline in Worm et al. (2009) was the most depleted Atlantic cod stock in Canada, which is widely regarded as one of the worst fishery disasters in the world.

Eastern oyster population dynamics center around positive feedback relationships between habitat quality and quantity, adult abundance, and recruitment, which must be incorporated into successful rehabilitation strategies (Mann \& Powell 2007). Eastern oysters have higher growth and survival rates on the top of high-relief reefs (Lenihan 1999). High relief promotes higher survival by keeping oysters out of areas that are anoxic or hypoxic, and growth rates may be promoted by higher flow over the top of reefs than near the base (Lenihan 1999). In addition, the tops of high-relief reefs also receive higher recruitment than low-relief reefs (Lenihan \& Peterson 1998, 2004, Lenihan 1999) and are less prone to habitat loss through siltation (Lenihan 1999, Smith et al. 2003). Increased recruitment on high quality habitat leads to increased adult abundance and increased egg production, which should lead to higher recruitment. Large oysters have higher fecundity and a higher proportion of females than small oysters, and shells from large, old oysters may be disproportionately important for reef accretion (Mann et al. 2009a,b). Increased recruitment and high growth rates lead to larger rates of habitat accretion, which further improves habitat quality. All of these factors are unavoidably linked because reductions in reef relief increase siltation (Lenihan 1999, Smith et al. 2003), which further reduces available habitat and, as a consequence, settlement and recruitment.

Excessive oyster harvest short-circuits the positive feedback cycle of reef accretion because fishing destroys habitat by removing shell and live oysters and breaking up the integrity of the reef (Lenihan \& Peterson 1998, 2004, Hargis \& Haven 1999). Dredging or hand tonging for only $2 \mathrm{~h}$ reduced reef height by 25 to $32 \mathrm{~cm}$ on an experimental set of small, recently constructed reefs in North Carolina, USA (Lenihan \& Peterson 1998, 2004). Although these 'reefs' were likely much less consolidated and more susceptible to fishing than natural ones, selective removal of only large, live oysters by divers still reduced reef height by $6 \mathrm{~cm}$. In comparison, the rate of habitat accretion is quite low for oysters. DeAltaris (1988) suggested that the rate of accretion was only $2 \mathrm{~cm} \mathrm{yr}^{-1}$ for an oyster reef in the James River, Virginia. Schulte et al. (2009) found somewhat higher accretion rates (2 to $6 \mathrm{~cm} \mathrm{yr}^{-1}$ ), in the Great Wicomico River on newly created reefs with a recent pulse of high recruitment, but the rate of habitat degradation from fishing is likely to substantially outpace accretion.

The failure to make substantive progress on oyster restoration should be noted, and new approaches must be considered. Strategies to rehabilitate oysters must focus on improving habitat through restoration activities, increasing adult abundance by eliminating or substantially reducing fishing, and stocking in areas where natural recruitment is poor (Brumbaugh et al. 2000). Habitat restoration efforts in Maryland have focused on maximizing the area over which shell is spread instead of building high-relief reefs, but this has not resulted in sustainable increases in highquality habitat (Smith et al. 2005, Mann \& Powell 2007). Attempts to reduce fishing activities have been made, including the designation of $\sim 25 \%$ of the Mary- 
land potion of Chesapeake Bay as sanctuaries, which is officially closed to oyster fishing. However, poaching in these areas remains a large problem (Paynter et al. 2010). In addition, power dredging (a more efficient method for fishing) has been allowed in a wider range of areas in recent years. The primary restoration strategies that are currently used are to increase stocking, which is currently being done with the goal of rearing 1 billion spat on shell per year for stocking efforts, and increasing the area of oyster sanctuaries to $\sim 25 \%$ of the total habitat. Despite substantial increases in stocking since 2000, oyster abundance has continued to decline.

\section{CONCLUSIONS}

While our study highlights the dire situation of oysters in the Maryland portion of Chesapeake Bay, there is still cause for optimism for some level of rehabilitation. Success of small-scale restoration projects indicates that populations can improve substantially when habitat restoration is combined with protection from fishing (Brumbaugh et al. 2000, Rodney \& Paynter 2006, Schulte et al. 2009). With prudent habitat restoration, a fishing closure, and fortuitously good recruitment, oyster abundance may be increased in a relatively short amount of time (Schulte et al. 2009). Modified habitat restoration techniques that include building high-relief reefs, combined with protection from fishing, allowed the oyster population in the Great Wicomico River to increase substantially within 3 yr (Schulte et al. 2009). Indeed, the adult population (age 1 and older) in that river would equal $14 \%$ of the population in Maryland and the Potomac River even though the restored habitat area was only $\sim 0.1 \%$ of habitat in Maryland and the Potomac River; furthermore, most of the oysters in Schulte et al. (2009) would have been categorized as small in our study. However, their study relied on natural recruitment, which has been lacking in much of Maryland waters of Chesapeake Bay during the last decade, and the long-term sustainability of the restoration effort is still uncertain. Thus, habitat restoration and closure to fishing combined with stocking of hatchery-reared juveniles may be a feasible way to increase population size and reverse habitat degradation (Brumbaugh et al. 2000, Rodney \& Paynter 2006). To date, stocking does not appear to have restored self-sustaining populations based on lack of recruitment to stocked reefs (Paynter et al. 2010), but stocked sites have often not been protected from fishing and were not selected to maximize spawning potential. Therefore, approaches are needed to select restoration and stocking sites to maximize spawning (e.g. North et al. 2010) and to protect them from fishing. Protection from fishing appears to be a necessary ingredient for successful rehabilitation, but, on its own, may not be sufficient to restore populations (Mann \& Powell 2007). We recommend that a moratorium on fishing should be imposed to minimize the risk of extirpation and provide an opportunity for recovery. Reefs and self-sustaining populations must be restored before fishing should be reopened.

Acknowledgements. This research was supported by the Maryland Department of Natural Resources (DNR). Maryland DNR and the Potomac River Fisheries Commission provided data. We thank M. Tarnowski, C. Judy, M. Naylor, K. Paynter, and A. C. Carpenter for data and discussions. J. Bence, L. Fegley, K. Fenske, V. Kennedy, D. Meritt, T. Miller, G. Nesslage, R. Newell, E. North, M. Palmer, and D. Secor provided helpful comments and suggestions. This is publication number 4506 of the University of Maryland Center for Environmental Science Chesapeake Biological Laboratory.

\section{LITERATURE CITED}

Albright BW, Abbe GR, McCollough CB, Barker LS, Dungan CF (2007) Growth and mortality of dermo-disease-free juvenile oysters (Crassostrea virginica) at three salinity regimes in an enzootic area of Chesapeake Bay. J Shellfish Res 26:451-463

Andrews JD (1988) Epizootiology of the disease caused by the oyster pathogen Perkinsus marinus and its effects on the oyster industry. Am Fish Soc Spec Publ 18:47-63

Baird D, Ulanowicz RE (1989) The seasonal dynamics of the Chesapeake Bay ecosystem. Ecol Monogr 59:329-364

Brooks SP, Gelman A (1998) General methods for monitoring convergence of iterative simulations. J Comput Graph Statist 7:434-455

Brooks WK (1905) The oyster. Johns Hopkins University Press, Baltimore, MD

Brumbaugh RD, Sorabella LA, Garcia CO, Goldsborough WJ, Wesson JA (2000) Making a case for community-based oyster restoration: an example from Hampton Roads, Virginia, USA. J Shellfish Res 19:467-472

Burnham KP, Anderson DR (2002) Model selection and multimodel inference. Springer-Verlag, New York, NY

Burreson EM, Ragone Calvo LM (1996) Epizootiology of Perkinsus marinus disease of oysters in the Chesapeake Bay with emphasis on data since 1985. J Shellfish Res 15: $17-34$

Cerco CF, Noel MR (2007) Can oyster restoration reverse cultural eutrophication in Chesapeake Bay? Estuar Coast 30:331-343

Chai A, Homer M, Tsai C, Goulletquer P (1992) Evaluation of oyster sampling efficiency of patent tongs and an oyster dredge. North Am J Fish Manag 12:825-832

Christmas JF, McGinty MR, Randle DA, Smith GF, Jordan SJ (1997) Oyster shell disarticulation in three Chesapeake Bay tributaries. J Shellfish Res 16:115-123

Coen LD, Luckenbach MW, Breitburg DL (1999) The role of oyster reefs as essential fish habitat: a review of current knowledge and some new perspectives. Am Fish Soc Symp 34:303-307

Coen LD, Brumbaugh RD, Bushek D, Grizzle R and others (2007) Ecosystem services related to oyster restoration. Mar Ecol Prog Ser 341:303-307 
Dame RF (1976) Energy flow in an intertidal oyster population. Estuar Coast Mar Sci 4:243-253

Dame R, Libes S (1993) Oyster reefs and nutrient retention in tidal creeks. J Exp Mar Biol Ecol 171:251-258

- DeAlteris JT (1988) The geomorphic development of Wreck Shoal, a subtidal oyster reef of the James River, Virginia. Estuaries 11:240-249

Environmental Protection Agency (EPA) (2000) Chesapeake Bay agreement. US EPA Chesapeake Bay Program, Annapolis, MD

Ford SE, Tripp MR (1996) Diseases and defense mechanisms. In: Kennedy VS, Newell RIE, Eble AF (eds) The eastern oyster: Crassostrea virginica. Maryland Sea Grant College, College Park, MD, p 581-660

Ford SE, Cummings MJ, Powell EN (2006) Estimating mortality in natural assemblages of oysters. Estuar Coast 29: 361-374

Fulford RS, Brietburg DL, Newell RIE, Kemp WM, Luckenbach M (2007) Effects of oyster population restoration strategies on phytoplankton biomass in Chesapeake Bay: a flexible modeling approach. Mar Ecol Prog Ser 336: 43-61

Fulford RS, Breitburg DL, Luckenbach M, Newell RIE (2010) Evaluating ecosystem response to oyster restoration and nutrient load reduction with a multispecies bioenergetics model. Ecol Appl 20:915-934

Gelman A, Carlin JB, Stern HS, Rubin DB (2004) Bayesian data analysis. Chapman \& Hall/CRC, New York, NY

Geweke J (1992) Evaluating the accuracy of sampling-based approaches to calculating posterior moments. In: Bernardo JM, Berger JO, Dawiv AP, Smith AFM (eds) Bayesian Statistics, Vol 4. Clarendon Press, Oxford, p 169-193

Grabowski JH, Peterson CH (2007) Restoring oyster reefs to recover ecosystem services. In: Cuddington $\mathrm{K}$, Byers JE, Wilson WG, Hastings A (eds) Ecosystem engineers: plants to protists. Academic Press, Amsterdam p 281-298

Grabowski JH, Hughes AR, Kimbro DL, Dolan MA (2005) How habitat setting influences restored oyster reef communities. Ecology 86:1926-1935

Hargis WJ Jr, Haven DS (1999) Chesapeake oyster reefs, their importance, destruction and guidelines for restoring them. In: Luckenbach MW, Mann R, Wesson JA (eds) Oyster reef habitat restoration: a synopsis and synthesis of approaches. Virginia Institute of Marine Science Press, Gloucester Point, VA, p 329-358

Harvell CD, Mitchell CE, Ward JR, Altizer S, Dobson AP, Ostfeld RS, Samuel MD (2002) Climate warming and disease risks for terrestrial and marine biota. Science 296: 2158-2162

Hilborn R, Mangel MM (1997) The ecological detective: confronting models with data. Princeton University Press, Princeton, NJ

Hinke WJ (1916) Report on the journey of Francis Louis Michel from Berne, Switzerland to Virginia, October 2, 1701-December 1, 1702. Va Mag Hist Biogr 24:1-43

Hofmann EE, Powell EN, Klinck JM, Saunders G (1995) Modelling diseased oyster populations. I. Modelling Perkinsus marinus infections in oysters. J Shellfish Res 14:121-151

Jackson JBC, Kirby MX, Berger WH, Bjorndal KA and others (2001) Historical overfishing and the recent collapse of coastal ecosystems. Science 293: 629-638

Jordan SJ, Greenhawk KN, McCollough CB, Vanisko J, Homer ML (2002) Oyster biomass abundance, and harvest in northern Chesapeake Bay: trends and forecasts. J Shellfish Res 21:733-741

Kemp WM, Boynton WR, Adolf JE, Boesch DF and others (2005) Eutrophication of Chesapeake Bay: historical trends and ecological interactions. Mar Ecol Prog Ser 303: $1-29$

Kennedy VS, Breisch LL (1983) Sixteen decades of political management of the oyster fishery in Maryland's Chesapeake Bay. J Environ Manag 164:153-171

Kirby M (2004) Fishing down the coast: historical expansion and collapse of oyster fisheries along continental margins. Proc Natl Acad Sci USA 101:13096-13099

Lenihan HS (1999) Physical-biological coupling on oyster reefs: how habitat structure influences individual performance. Ecol Monogr 69:251-275

Lenihan HS, Peterson CH (1998) How habitat degradation through fishery disturbance enhances impacts of hypoxia on oyster reefs. Ecol Appl 8:128-140

Lenihan HS, Peterson CH (2004) Conserving oyster reef habitat by switching from dredging and tonging to diverharvesting. Fish Bull 102:298-305

Limburg KE, Waldman JR (2009) Dramatic declines in North Atlantic diadromous fishes. BioScience 59:955-965

Lotze HK, Lenihan HS, Bourque BJ, Bradbury RH and others (2006) Depletion, degradation, and recovery potential of estuaries and coastal seas. Science 312:1806-1809

Mann R, Powell EN (2007) Why oyster restoration goals in the Chesapeake Bay are not and probably cannot be achieved. J Shellfish Res 26:1-13

Mann R, Southworth M, Harding JM, Wesson J (2004) A comparison of dredge and patent tongs for estimation of oyster populations. J Shellfish Res 23:387-390

> Mann RM, Harding JM, Southworth M (2009a) Reconstructing pre-colonial oyster demographics in the Chesapeake Bay, USA. Estuar Coast Shelf Sci 85:217-222

> Mann RM, Southworth M, Harding JM, Wesson JA (2009b) Population studies of the native oyster, Crassostrea virginica (Gmelin, 1791) in the James River, Virginia, USA. J Shellfish Res 28:193-220

Maryland Department of Natural Resources (MD DNR) (2009) Oyster restoration and aquaculture development plan. Available at: www.dnr.state.md.us/fisheries/oysters/pdfs/ GovernorsOfficeSlidesFinal.pdf

McCullagh P, Nelder JA (1989) Generalized linear models. Chapman \& Hall, New York, NY

Myers RA, Bowen KG, Barrowman NJ (1999) Maximum reproductive rate of fish at low population sizes. Can J Fish Aquat Sci 56:2404-2419

Newell RIE (1988) Ecological changes in Chesapeake Bay: Are they the result of overharvesting the American oyster, Crassostrea virginica? In: Lynch MP, Krome EC (eds) Understanding the estuary: advances in Chesapeake Bay research. Chesapeake Research Consortium Publ 129, Gloucester Point, VA, p 536-546

North EW, King DM, Xu J, Hood RR and others (2010) Linking optimization and ecological models in a decision support tool for oyster restoration and management. Ecol Appl 20:851-866

> Patterson KR (1996) Modelling the impact of disease-induced mortality in an exploited population: the outbreak of the fungal parasite Ichthyophonus hoferi in the North Sea herring (Clupea harengus). Can J Fish Aquat Sci 53: 2870-2887

Paynter KT (2007) A 10-year review of Maryland's hatcherybased oyster restoration program 1997-2006: a summary of monitoring and research conducted by the Paynter Laboratory at the University of Maryland. Tech Rep, University of Maryland Center for Environmental Science, CBL 07-184. Chesapeake Biological Laboratory, Solomons, MD

> Paynter KT, Politano V, Lane HA, Meritt D (2010) Growth rates a prevalence of Perkinsus marinus prevalence in 
restored oyster populations in Maryland. J Shellfish Res 29:309-317

Peterson CH, Grabowski JH, Powers SP (2003) Estimated enhancement of fish production resulting from restoring oyster reef habitat: quantitative valuation. Mar Ecol Prog Ser 264:249-264

Porter ET, Cornwell JC, Sanford LP (2004) Effect of oysters Crassostrea virginica and bottom shear velocity on benthic-pelagic coupling and estuarine water quality. Mar Ecol Prog Ser 271:61-75

Powell EN, Klinck JM (2007) Is oyster shell a sustainable estuarine resource? J Shellfish Res 26:181-194

Powell EN, Klinck JM, Hofmann EE (1996) Modelling diseased oyster populations. II. Triggering mechanisms for Perkinsus marinus epizootics. J Shellfish Res 15:141-165

Powell EN, Ashton-Alcox KA, Kraeuter JN (2007) Reevaluation of oyster dredge efficiency in survey mode: application in stock assessment. N Am J Fish Manag 27: 492-511

Rodney WS, Paynter KT (2006) Comparisons of macrofaunal assemblages on restored and non-restored oyster reefs in mesohaline regions of Chesapeake Bay in Maryland. J Exp Mar Biol Ecol 335:39-51

Rothschild BJ, Ault JS, Goulletquer P, Héral M (1994) Decline of the Chesapeake Bay oyster population: a century of habitat destruction and overfishing. Mar Ecol Prog Ser 111:29-39

Schulte DM, Burke RP, Lipcius RN (2009) Unprecedented restoration of a native oyster metapopulation. Science 325: 1124-1128

Smith GF, Greenhawk KN, Bruce DG, Roach EB, Jordan SJ

Editorial responsibility: Charles Peterson,

Morehead City, North Carolina, USA
(2001) A digital presentation of the Maryland oyster habitat and associated bottom types in the Chesapeake Bay (1974-1983). J Shellfish Res 20:197-206

Smith GF, Bruce DG, Roach EB (2003) The location, composition and origin of oyster bars in mesohaline Chesapeake Bay. Estuar Coast Shelf Sci 56:391-409

Smith GF, Bruce DG, Roach EB, Hansen A, Newell RIE, McManus AM (2005) Assessment of recent habitat conditions of eastern oyster Crassostrea virginica bars in mesohaline Chesapeake Bay. N Am J Fish Manag 25: 1569-1590

Southworth M, Harding JM, Wesson JA, Mann R (2010) Oyster (Crassostrea virginica) population dynamics on public reefs in the Great Wicomico River, Virginia, USA. J Shellfish Res 29:271-290

Tarnowski MT (2007) Maryland oyster population status report. Maryland Department of Natural Resources, Annapolis, MD

- Thurstan RH, Brockington S, Roberts CM (2010) The effects of 118 years of industrial fishing on UK bottom trawl fisheries. Nat Commun 1:15

> Vølstad JH, Dew J, Tarnowski M (2008) Estimation of annual mortality rates for eastern oysters (Crassostrea virginica) in Chesapeake Bay based on box counts and application of those rates to project population growth of $C$. virginica and C. ariakensis. J Shellfish Res 27:525-533

> Williams EH, Shertzer KW (2003) Implications of life-history invariants for biological reference points used in fishery management. Can J Fish Aquat Sci 60:710-720

Worm B, Hilborn R, Baum JK, Branch TA and others (2009) Rebuilding global fisheries. Science 325:578-585

Submitted: September 30, 2010; Accepted: April 7, 2011 Proofs received from author(s): August 24, 2011 